\title{
Skin Response Reason Not Done
}

National Cancer Institute

\section{Source}

National Cancer Institute. Skin Response Reason Not Done. NCI Thesaurus. Code C117685.

The rationale why a skin response test was not performed. 